\title{
Interventions in agriculture to benefit nutrition and health in Portuguese-Speaking Countries
}

\section{Intervir na agricultura em beneficio da nutrição e da saúde na CPLP}

\author{
Luís F. Goulão \\ Instituto de Investigação Científica Tropical (IICT, IP), Tapada da Ajuda 1349-017 Lisboa, Portugal \\ Email: luisfgoulao@gmail.com
}

Afiliação atual: LEAF, Instituto Superior de Agronomia, Universidade de Lisboa, Tapada da Ajuda 1349-017 Lisboa,
Portugal

Este artigo foi apresentado como comunicação oral no seminário "Segurança Alimentar e Nutricional na Medicina Tropical caminhos comuns na CPLP", realizado como encontro satélite do $3^{\circ}$ Congresso Nacional de Medicina Tropical, no dia 17 de

Abril de 2015

\begin{abstract}
Ensuring adequate levels of Food and Nutritional Security (FNS) and, thus, contributing to socio-economic growth in developing countries requires integrated and multi-sectorial approaches. Under this scenario, turning agriculture more sensitive to nutrition has been the subject of great focus. In this communication, some examples of how and where to intervene in agriculture for the benefit of the populations' nutrition and health status, framing the current priorities and agendas of international development, with an emphasis on the Portuguese-speaking countries community (CPLP), are reviewed.
\end{abstract}

Keywords: agriculture, CPLP: Portuguese-Speaking countries, development, food and nutritional security, nutrition.

\section{Resumo}

Garantir níveis adequados de SAN e, com isso, contribuir para o crescimento socioeconómico em países em desenvolvimento exige abordagens integradas e multissetoriais, sendo que tornar a agricultura mais sensível à nutrição, tem sido alvo de grande foco. Nesta comunicação, são revistos alguns exemplos de como e onde intervir na agricultura em benefício da nutrição e da saúde das populações, enquadrando o atual momento nas prioridades e agendas de desenvolvimento internacionais, com ênfase na CPLP.

Palavras-chave: agricultura, CPLP, desenvolvimento, nutrição, segurança alimentar e nutricional 
The value of adequate food was proclaimed in the 1948 Universal Declaration of Human Rights article no. 25. This declaration identifies food as a right and details that it only can be ensured when all people have, at all times, purchasing capacity and physical access to food in an adequate quantity and quality, without compromising other basic needs, to ensure the dietary requirements for a healthy and productive life, respecting cultural diversity and observing social-economic and environmental sustainability. Even though, in recent decades, the political efforts for food security have been geared towards providing nations with the capacity to attain abundant food production, this definition stresses "dietary needs" and "healthy and productive life," unequivocally raising nutrition and health dimensions to the food security arena (Figure 1). The concept of Food and Nutritional Security (FNS) was thus engendered to add food with the quality and safety dimensions (including composition and nutritional value), sustained in dietary practices that promote health. FNS became a main goal, moving beyond the sole fulfillment of householders' calories requirements and national sovereignty in agro-food production. FNS further entails a clean environment, with proper care and health services. The so-called "hidden hunger" caused by lack or low consumption of micronutrients (vitamins and minerals) affects more than an estimated 2 billion people around the world ${ }^{1}$ and, in tropical Africa, is the main problem of public health, leading to high mortality and low economic productivity ${ }^{2}$.
O direito à alimentação adequada está contemplado no artigo 25 da Declaração Universal dos Direitos Humanos de 1948. O texto que consagra a alimentação como um direito humano refere que este é assegurado quando todas as pessoas possuem, durante todo o tempo, poder de compra e acesso físico a alimentos em quantidade e qualidade suficiente, sem comprometer outras necessidades essenciais, para garantir as necessidades dietéticas para uma vida saudável e produtiva, que respeitem a diversidade cultural e que sejam social, económica e ambientalmente sustentáveis. Apesar de, nas últimas décadas, os esforços das políticas de Segurança Alimentar se terem voltado para dotar as nações de capacidade para uma produção abundante de alimentos, esta definição sublinha "necessidades dietéticas" e "vida saudável e produtiva", ligando de forma inequívoca as dimensões da nutrição e da saúde à questão da segurança alimentar (Figura 1). O conceito de Segurança Alimentar e Nutricional (SAN) surge, assim, para incluir as dimensões de segurança e de qualidade (incluindo composição e valor nutricional) aos alimentos, tendo por base práticas alimentares que promovam a saúde e recentra os objetivos centrais, para além da questão do suprimento das necessidades calóricas dos membros do agregado familiar das populações e autossuficiências nacionais, na produção agroalimentar. SAN implica a existência de um ambiente salubre, serviços de saúde e cuidados adequados. A denominada "fome oculta" que surge como consequência da falta ou do baixo consumo de micronutrientes (vitaminas e minerais) afeta mais de 2 mil milhões de pessoas em todo o mundo $^{1}$ e é, na África tropical, o principal problema de saúde pública, registando-se mortalidade e baixa produtividade económica $^{2}$.

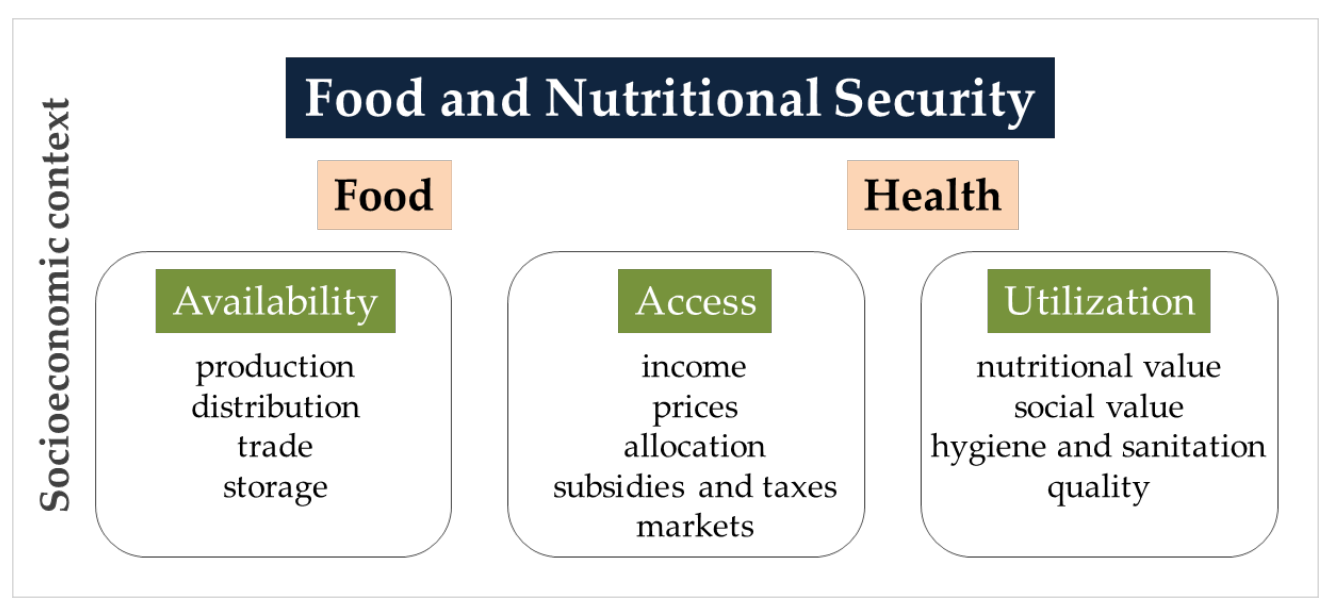

Figure 1 - The Food-Health binomial represented in the main three pillars of food and nutritional security. The fourth pillar "stability" aims at ensuring a stable environment and the attentiveness required to face emergencies of social-natural origin. 


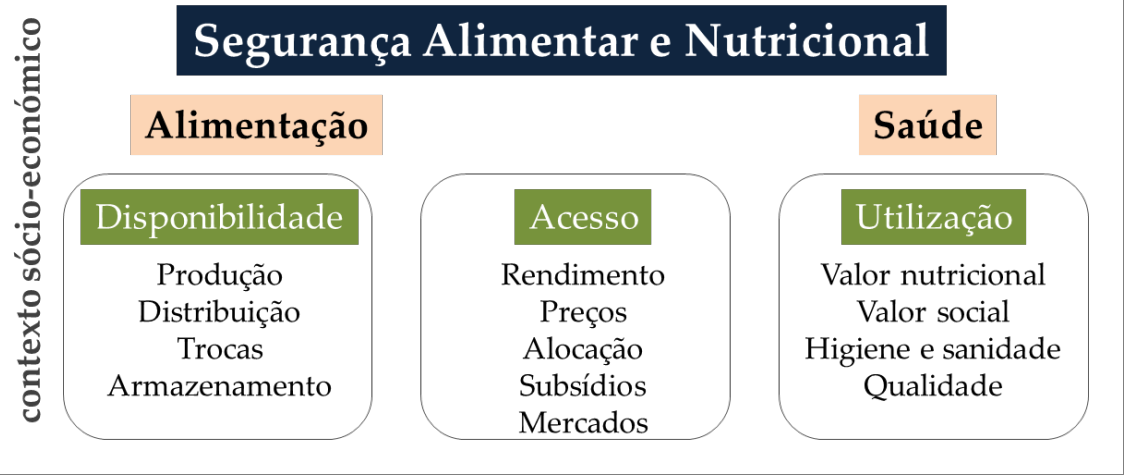

Figura 1 - Binómio Alimentação - Saúde em três pilares da Segurança Alimentar e Nutricional. O quarto pilar "estabilidade" visa garantir a estabilidade da produção e os cuidados necessários frente a emergências de origem sócionatural.

On the other hand, right to food is also attentive in respecting cultural attitudes, societal organization structures, economic frameworks and natural environment. In so, FNS is multidimensional to include food quality, environmental conditions for their production, sustainable development and livelihoods' well-being and life quality.

Ensuring adequate FNS and, thus, contributing to socio-economic growth in developing countries, requires integrated and multi-sectorial approaches. Under this scenario, adapting agriculture to be more sensitive to nutrition has been the subject of great focus. The agricultural sector is challenged to establish new dialogue and partnership models with other sectors, in particular, education, water and sanitation.

\section{Food - Health - Development}

Malnutrition has long-term consequences with huge impact on social development. This phenomenon, in particular in the mother-child population segment, is responsible for about $45 \%$ child mortality in children under five years of age. The greatest impact is observed during the first 1000 days of life ${ }^{3}$. On the other hand, is it well known that undernutrition may impair the physical and cognitive development, as well as being an increased risk of developing non-communicable diseases throughout life 4 ."Hidden hunger" can hamper multiple steps of several metabolic processes, leading to disturbances in the immune system, and both physical and mental development, which predisposes or aggravates the progression of a number of diseases. Vitamin A, iron and iodine are the three major nutritional deficiencies worldwide and have been a priority to the World Health Organization (WHO). These health problems, which are often associated with difficulties in accessing
Por outro lado, o direito consagrado à alimentação não esquece o respeito pela cultura, sociedade, economia e ambiente. O conceito de SAN envolve, portanto, a qualidade dos alimentos, as condições ambientais para a sua produção, o desenvolvimento sustentável e a qualidade de vida das populações.

Garantir níveis adequados de SAN e, com isso, contribuir para o crescimento socioeconómico em países em desenvolvimento exige abordagens integradas e multissetoriais, sendo que tornar a agricultura mais sensível à nutrição tem sido alvo de grande foco. Neste contexto, é certo que o setor agrícola terá que estabelecer novas formas de parceria com outros setores, em particular com a educação, água e saneamento.

\section{Alimentação - Saúde - Desenvolvimento}

A desnutrição tem consequências a longo prazo com grande impacto no desenvolvimento social. Este fenómeno, em particular no segmento materno-infantil, é responsável por cerca de $45 \%$ da mortalidade em menores de 5 anos, com maior impacto nos primeiros 1000 dias de vida ${ }^{3}$. Por outro lado, é aceite que a desnutrição pode comprometer o desenvolvimento físico e cognitivo, bem como constituir um risco acrescido para as doenças não-transmissíveis ao longo da vida ${ }^{4}$. A "fome oculta" pode comprometer várias etapas do processo metabólico, com alterações no sistema imunológico, nas defesas antioxidantes e no desenvolvimento físico e mental, predispondo ou agravando o desenvolvimento de diversas doenças. Em particular, as deficiências de vitamina $\mathrm{A}$, ferro e iodo são as três maiores carências nutricionais mundiais e têm sido uma prioridade para a Organização Mundial da Saúde (OMS). Estes problemas de saúde, frequentemente associados à dificuldade 
to food, lead to decreased competitiveness, productivity and societal economic growth, consequently generating poverty, and, in a vicious cycle, provoking a persistent difficulty in the access to food by the populations (Figure 2).

In this cycle, social and cultural factors associated with low development have then an impact on the nutritional status of a population. Thus, since nutrition has paramount importance in limiting the economic growth, it is currently recognized that the populations' nutritional status is a key priority for development. de acesso aos alimentos, conduzem a uma menor competitividade, produtividade e crescimento económico das sociedades, gerando consequentemente pobreza, e levando, num ciclo vicioso, a que se mantenham as dificuldades da população no que respeita ao acesso a alimentos (Figura 2).

Neste ciclo, os fatores sociais e culturais associados a um baixo índice de desenvolvimento produzem consequentemente impactos no estado nutricional das populações. Assim, a nutrição é um importante fator limitante do crescimento socioeconómico, sendo atualmente reconhecido que a situação nutricional das populações constitui uma prioridade essencial para ocorrer desenvolvimento.

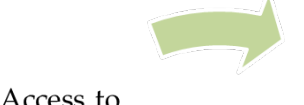

Access to food

productivity

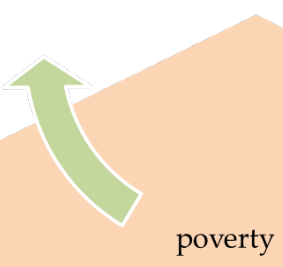

MALNUTRITION:

- Child mortality

- Growth disturbances

- Disturbances in the development of cognitive aptitudes

- Increased risk of non-communicable diseases throughout life

Figure 2 - Relationship cycle between difficulties in accessing to food and productivity, with consequences to the development of individuals and nations.

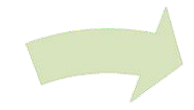
Acesso a
Produtividade
alimentos

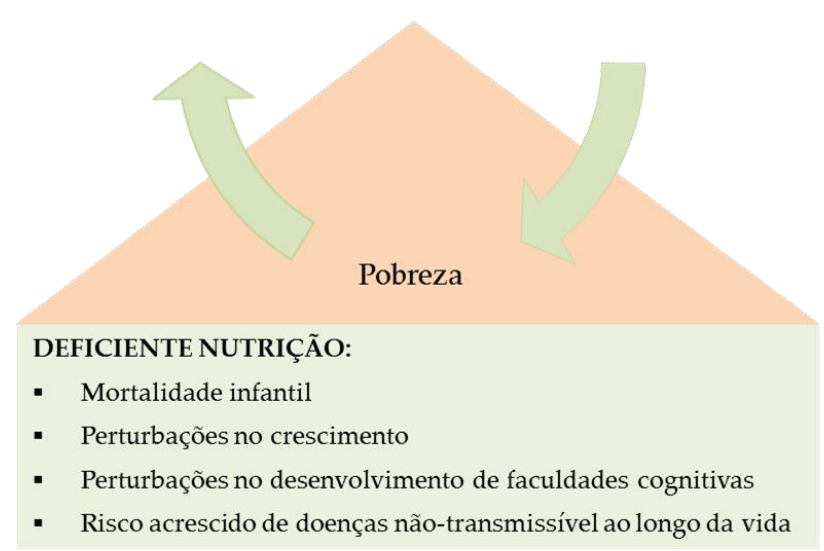

Figura 2 - Ciclo de relação entre dificuldades em ter acesso a alimentos e níveis de produtividade, com implicações no desenvolvimento dos indivíduos e dos países. 


\section{Priorities in Policy Agendas}

Achieving the United Nations Sustainable Development Goals (SDG), proclaimed in September 2015 to guide national policies and international cooperation activities during the next 15 years (to update the Millennium Developmental Goals (MDGs)), became a priority to the international community. Malnutrition was recognized in the SDG document as one major challenge to attain sustainable development.

Globalization promotes North-South food supply systems convergences, engendering both opportunities and common challenges. Hence, intervening in agriculture to benefit nutrition, through multisector approaches, was adopted as a global priority to respond to local needs, triggering renewed attention in national and international public organizations, international agencies, the private sector (including international agriculture and food companies) and civil society, such as United Nations Food and Agriculture Organization (FAO), World Health Organization (WHO), United Nations Children's Fund (UNICEF), United Nations World Food Program, World Bank, United Nations Development Program (UNDP), International Fund for Agricultural Development (IFAD), International Food Policy Research Institute (IFPRI), Children's Investment Fund Foundation (CIFF), Bill \& Melinda Gates Foundation (BMGF), Global Alliance for Improved Nutrition (GAIN), or international Non-Governmental organizations (NGOs) such as Cooperative for Assistance and Relief Everywhere (Care), Helen Keller International (HKI) or Action Against Hunger (AAH) - ACF International.

These organizations became engaged with several levels of commitment in a number of programs, such as, the UKBrazilCIFF "Nutrition for Growth", the "Global Targets 2025", the FAO/WHO "Second International Conference on Nutrition (ICN2)", the "Scaling Up Nutrition (SUN)", the "Renewed Efforts Against Child Hunger and Undernutrition (REACH)", the FAO/ UNICEF/WHO World Food Program (WFP), the IFPRI "Global Nutrition Reports (GNR)", the Institute for International Programs at the Johns Hopkins Bloomberg School of Public Health (IIP-JHU) "National Evaluation Platforms (NEP)", the "Gender Alliance Informed Nutrition and Agriculture (GINA)", the US Agency for International Development (USAID) Collaborative Research Nutrition Support Program (NCRSP), and other emerging initiatives such as the European Commission / AGRINATURA "National Information Platforms for Nutrition: Global Support Facility" (NIPN-GSF), the IFPRI "Compact 2025" program, and the United Na-

\section{Prioridade nas Agendas Políticas}

Os Objetivos de Desenvolvimento Sustentável (ODS) da ONU, proclamados em setembro de 2015, e que deverão orientar as políticas nacionais e as atividades de cooperação internacional nos próximos 15 anos, atualizam os Objetivos de Desenvolvimento do Milénio (ODM) e são uma prioridade assumida pela comunidade internacional. Nos ODS, a desnutrição surge enunciada como um dos principais desafios ao desenvolvimento sustentável.

A globalização promove a convergência dos sistemas de alimentação Norte-Sul, gerando oportunidades e desafios comuns. Este fato faz com que intervir na agricultura, em benefício da nutrição através de abordagens multissetoriais, seja atualmente uma prioridade global para responder a necessidades locais, despertando renovado interesse em organizações públicas nacionais e internacionais, agências internacionais, privados (incluindo empresas internacionais dos setores agrícola e alimentar) e sociedade civil, como a Organização das Nações Unidas para a Agricultura e Alimentação (FAO), a Organização Mundial de Saúde (OMS), a United Nations Children's Fund (UNICEF), o UN World Food Programme, o Banco Mundial, o United Nations Development Programme (UNDP), o International Fund for Agricultural Development (IFAD), o International Food Policy Research Institute (IFPRI), a Children's Investment Fund Foundation (CIFF), a Fundação Bill \& Melinda Gates (BMGF), a Aliança Global para uma Melhor Nutrição (GAIN), ou Organizações Não-Governamentais internacionais (ONGs) como a Cooperative for Assistance and Relief Everywhere (Care), a Helen Keller International (HKI) ou a Action Against Hunger (AAH) - ACF International.

Estas entidades assumiram diversos programas e níveis de comprometimento, como por exemplo o UK/ Brazil/CIFF "Nutrition for Growth", os "Global targets 2025" da OMS, a "Second International Conference on Nutrition (ICN2)" da FAO/OMS, a "Scaling Up Nutrition (SUN)", a "Renewed Efforts Against Child Hunger and undernutrition (REACH)" da FAO/UNICEF/OMS/ World Food Programme (WFP), os "Global Nutrition Reports (GNR)" do IFPRI, as "National Evaluation Platforms (NEP)" do Institute for International Programs na John Hopkins Bloomberg School of Public Health (IIP-JHU), a Aliança "Gender Informed Nutrition and Agriculture (GINA) / "Nutrition Collaborative Reserarch Support Program (NCRSP)" da US Agency for International Development (USAID) e iniciativas emergentes como as "National Information Platforms for Nutrition: Global Support Facility NIPN/GSF" de 
tions Standing Committee on Nutrition (UNSCN), amongst others.

The foremost intrinsic goal shared in these initiatives is to raise awareness among the society and political, business and health leaders to malnutrition, promoting a debate to leverage solutions development and implementation, while assisting, in the short term, the needs of the most vulnerable populations.

During the XVI Portuguese-Speaking Countries Community (CPLP) Council of Ministers Ordinary Meeting, held in 2011, in Luanda, Angola, a CPLP Strategy for Food and Nutritional Security (ESAN-CPLP) was approved, with a strategic goal of assisting a gradual institutionalization of the FNS subject in all member countries and setting its governance at the regional level. The strategy was presented at the 37th Committee of World Food Security meeting.

In the Maputo Declaration, signed in 2012 by the Heads of State of all CPLP countries, a statement on the topic "the CPLP and the food and nutritional security challenges" was adopted. This declaration stresses that ESAN-CPLP's overall objective is to contribute to the recognition of the human right to adequate food and eradication of hunger and poverty in the community, and is to be materialized by the establishment of a CPLP Food and Nutritional Security Council (CONSAN-CPLP). CONSAN is a multi-stakeholder ministerial platform accountable for the harmonization of FNS actions and for advising the CPLP Heads of State and their governments, aiming to promote inter-sectorial approaches and social participation in the coordination of FNS policies, legislation and programmatic activities to provide a contribution in implementing the ESAN-CPLP's established priorities.

In 2014, the FAO's General Director and the CPLP Executive Secretary signed a technical cooperation program between the two organizations to strengthen the ESAN-CPLP execution. More recently, during the CONSAN-CPLP Meeting held in Dili, East-Timor November 2015, the political will and commitment for eradication of hunger and poverty was reaffirmed, which steered the CPLP Member States to set the foundations for a common understanding, resulting in the adoption of ESAN-CPLP. The importance of its rapid implementation was recognized, particularly regarding its governance mechanisms structure at national and regional levels, and the activities plans that should result from the coordination of efforts among the several actors and stakeholders involved. iniciativa da Comissão Europeia e o envolvimento da rede AGRINATURA, o programa "Compact 2025" do IFPRI, ou o "United Nations Standing Committee on Nutrition (UNSCN)", entre outras.

O grande objetivo comum inerente a estas iniciativas é alertar e consciencializar sociedades, líderes políticos, de saúde e de negócios para o problema da desnutrição e outras formas de malnutrição, promovendo o debate que leve a explorar e implementar soluções, ao mesmo tempo que apoiam, a curto prazo, as populações mais vulneráveis.

$\mathrm{Na}$ Comunidade de Países de Língua Portuguesa (CPLP), foi aprovada a Estratégia de Segurança Alimentar e Nutricional da CPLP (ESAN-CPLP) pela XVI Reunião Ordinária do Conselho de Ministros, em Luanda, em 2011, com vista à institucionalização progressiva do tema Segurança Alimentar e Nutricional na CPLP e da sua governabilidade ao nível regional, sendo apresentada à $37^{\mathrm{a}}$ Reunião do Comité Mundial de Segurança Alimentar.

Na Declaração de Maputo, de 2012, os Chefes de Estado de todos os países da CPLP aprovaram uma Declaração sobre o tema "A CPLP e os Desafios da Segurança Alimentar e Nutricional", realçando que o objetivo global da ESAN-CPLP é o de contribuir para a concretização do direito humano à alimentação adequada e erradicação da fome e da pobreza na Comunidade, e acordaram quanto à constituição de um Conselho de Segurança Alimentar e Nutricional da CPLP (CONSAN-CPLP). O CONSAN é uma plataforma ministerial de multiatores para a coordenação das ações desenvolvidas na área de SAN e de assessoria aos Chefes de Estado e de Governo da CPLP, para promover a intersetorialidade e a participação social na coordenação de políticas, legislação e programas de ações para a SAN e, por esta via, contribuir para materializar a prioridade estabelecida na ESAN-CPLP.

Em 2014, o diretor geral da FAO e o secretário executivo da CPLP assinaram um programa de cooperação técnica entre as duas organizações que visa reforçar a implementação da ESAN-CPLP. Mais recentemente, em novembro de 2015, o CONSAN-CPLP, reunido em Díli, Timor-Leste, reafirmou a vontade política e o compromisso com a erradicação da fome e da pobreza, que conduziram os Estados-membros da CPLP a definir as bases de entendimento comum, que resultaram na aprovação da ESAN-CPLP e reconheceu a importância da rápida implementação da ESAN-CPLP, em particular, no tocante à construção dos seus mecanismos de governança ao nível nacional e regional, bem como planos de atividades resultantes da coordenação de esforços entre os vários atores envolvidos. 


\section{How and where to intervene}

Food and agriculture are the bases of proper nutrition. Despite being a cross-cutting issue that requires multidimensional, multi-sectorial policies, interventions in agriculture and education on nutrition activities have been confirmed to hold the highest potential to significantly contribute in reducing malnutrition. It is also recognized that Gross Domestic Product (GDP) growth generated from agricultural activities is at least twice as effective in benefiting the poorest half of the population as growth generated by the other sectors 5 . Thus, when taking interventions in agriculture as a priority, it is envisioned to simultaneously maximize the impact of agriculture on tangible results and to integrate clear objective indicators of nutrition in the agricultural investment plans.

Adopting a value-chain perspective ${ }^{6}$, the potential of a food for nutrition develops from:

- Nutritional quality: is the product rich in vitamins, minerals and proteins (e.g., vitamin A and iron) to address the most vulnerable sectors of the population?

- Availability: is the product available in vulnerable regions and can the households' access it in places of their convenience?

- Cost: is the price affordable to a poor population?

- Acceptability: is there evidence that they want to consume the product? Is it part of the present-day diet?

- Transparency: Can consumers get information on the nutritional quality of the product? Is it possible to reflect quality in the product price by the market?

Bearing in mind that, in terms of innovation, technology and investment, the implementation of policies adapted to specific contexts is mandatory, shifting agriculture to be more sensitive to nutrition relies on research, understanding, and respect

\section{Research and understanding:}

- How to shape value chains to provide nutritious foods, with minimum loss of quality and value and with high levels of safety, including processed foods;

- How to improve the nutritional value of foods, through germplasm selection and breeding;

- Consumers' perception about healthy diets and nutrition;

- Perception on how educational and incentives systems can improve diets;

- Perception of the influence of urbanization and markets on rural-urban relations and their impact on the future of agriculture;

- Understanding the nutritional transition phenomenon.

\section{Como e onde intervir}

A agricultura e a alimentação são as bases de uma adequada nutrição. Apesar de ser uma questão transversal que requer políticas e medidas multissetoriais e de natureza multidimensional, as intervenções na agricultura e ações de educação nutricional são aquelas que demonstram maior potencial para contribuir de forma significativa na redução da malnutrição. É, ainda, reconhecido que crescimentos no Produto Interno Bruto (PIB) com origem na atividade agrícola é, pelo menos, duas vezes mais eficaz para beneficiar a metade mais pobre da população do que o crescimento gerado noutros setores ${ }^{5}$. Assim, ao considerar prioritária a intervenção na agricultura, pretende-se simultaneamente maximizar o impacto da agricultura em resultados tangíveis de nutrição e incorporar objetivos e indicadores claros de nutrição nos investimentos agrícolas.

Numa perspetiva de cadeia de valor ${ }^{6}$, o potencial de um alimento para nutrição deriva de:

- Qualidade Nutricional: o produto é rico em vitaminas, minerais e proteína (ex: vitamina A e ferro) para atender setores da população mais vulneráveis?

- Disponibilidade: o produto está disponível em regiões vulneráveis e podem as populações aceder em locais de sua conveniência?

- Custo: o preço é comportável por uma população pobre?

- Aceitabilidade: existe evidência que os consumidores querem consumir este produto? Faz parte da dieta atual?

- Transparência: Podem os consumidores conhecer a qualidade nutricional do produto? Pode o mercado refletir esta qualidade no preço?

Tendo presente que, em termos de inovação, tecnologia e investimento, é essencial a implementação de políticas adaptadas a contextos específicos, tornar a agricultura mais sensível à nutrição passa por investigar, compreender e respeitar.

\section{Investigar e compreender:}

- Como organizar as cadeias de valor para fornecer alimentos nutritivos, com perdas mínimas de valor e elevados níveis de segurança, incluindo alimentos processados;

- Como melhorar o valor nutricional dos alimentos, através de seleção e melhoramento;

- Perceção por parte dos consumidores dos conceitos de dieta saudável e nutrição;

- Perceção de como sistemas educativos e de incentivos podem melhorar as dietas;

- Perceção do impacto da urbanização e mercados nas 


\section{Understanding and respect:}

- Social and cultural obstructions to changes in the agriculture sector: tradition, diversity of beliefs and cultures, responsibilities and social duties, etc.;

- Cultural basis of agricultural systems: household, family and social structures and organizations, gender issues, social compartmentations and divisions, religion;

- Nature of social-economic interests: formal and informal leaders, local interest groups, social expectations, cultural values;

- Specific features of agricultural systems: diversity and type of farming practices in accordance to traditions and culture, land tenure and access, heritage, festivals and ceremonies, traditional forms of communication, etc.;

- Drivers of changes: innovation, leadership, interaction with different cultures, communication, population growth;

- Societal changes: young unemployment, rural-to-urban migratory fluxes.

Associated with public investment in other nutrition-related sectors and bearing in mind the target group(s) and channels, looking though the production chain lens (Figure 3), shifting agriculture more sensitive to nutrition relies in interventions such as:

- Engender increased yield, productivity and income;

- Dietary diversification;

- Increased and improved exploitation of legumes and pulses (intercropping with cereals), fruits and vegetables, underutilized and native species;

- Production of meat, fish, algae, insects;

- Use of improved varieties, resulting from selection or breeding, including biofortification;

- Adoption of post-harvest and processing methods that preserve product quality.

"Acting locally" through the advertising of producing and consuming local foods with high nutritional value should be the target goal to achieve the anticipated results in the short term, since it allows respect of cultural patterns, which promotes an easy acceptance and makes use of well adapted biological material, enabling appropriate yields. Such combinations of factors will contribute, significantly and promptly, to the improvement of the nutritional condition of vulnerable populations and show the additional advantage of assuring that the systems are more resilient to climate changes. Hence, comprehensive information about the identity of available foods and how they can and should be used is mandatory. ligações rural-urbano e como afetam o futuro da agricultura;

- Compreensão do fenómeno de transição nutricional.

\section{Compreender e respeitar:}

- Barreiras sociais e culturais às mudanças na agricultura: tradição, diversidade de crenças e culturas, responsabilidades e obrigações sociais, etc;

- Base cultural dos sistemas agrícolas: estrutura e organização social e familiar, género, divisões sociais e religião;

- Natureza de interesses económicos e sociais: líderes formais e informais, grupos de interesse locais, expectativas sociais e cultura;

- Características específicas dos sistemas agrícolas: diversidade e tipo de práticas agrícolas de acordo com tradições e cultura, acesso e posse da terra, heranças, festivais e cerimónias, meios tradicionais de comunicação, etc;

- Fatores de mudança: inovação, liderança, contacto com outras culturas, comunicação e crescimento populacional;

- Mudanças sociais: desemprego jovem e migrações rural-urbano.

Associado a investimento público nos restantes setores relacionados com a nutrição e tendo sempre presente quais o(s) grupo(s)-alvo e os canais, do ponto da cadeia de produção (Figura 3), tornar a agricultura mais sensível à nutrição passa por intervenções como:

- Gerar um aumento da produtividade e renda;

- Diversificação de dietas;

- Maior exploração de leguminosas (consociações com cereais), frutas e legumes, espécies nativas sub-exploradas;

- Produção de carne, peixe, algas, insetos;

- Utilização de variedades melhoradas, incluindo biofortificação;

- Adoção de métodos de pós-colheita e processamento que preservem a qualidade dos produtos.

“Agir localmente", através da promoção do cultivo e do consumo de alimentos locais com elevado valor nutritivo deverá constituir uma forte aposta para que se atinjam os resultados desejados a curto prazo, uma vez que permite respeitar padrões culturais, o que potencia uma adoção fácil e utiliza material biológico bem adaptado, possibilitando produções adequadas. Esta combinação de fatores vai contribuir, de forma significativa e rápida, para a melhoria da condição nutricional das populações vulneráveis e tem a vantagem acrescida de tornar os sistemas mais resilientes ao fenómeno das alterações climáticas. Para tal, é necessário conhecer quais são os 
The species Moringa oleifera stands as a case-of-study of international commercial success. Growing in Africa and Asia tropical regions and used by local populations for food and medicine, this species' dried leaves are 10 times richer in vitamin A than carrots, 15 times richer in potassium than bananas, 17 times richer in calcium than milk, 25 times richer in iron than spinach, 9 times richer in protein than milk, and has half the vitamin $\mathrm{C}$ of an orange ${ }^{8}$. Numerous indigenous or locally adapted species with a high nutritional value exist, and most of them are neglected. The potential frequently exists and the product is affordable, but requires efforts to inform the populations and households about their true value as food, and the possible ways of utilization, in order to fully explore their benefits.

The organization and development of novel value chains for high nutritional value local underutilized species stands as an encouraging strategy to improve health and conditions to create income for rural communities, leveraging development at national level. alimentos que se encontram disponíveis e de que forma podem e devem ser utilizados.

A Moringa oleifera representa um caso-de-estudo pelo sucesso comercial internacional recente. Presente em regiões tropicais da Ásia e África e usada localmente, por algumas populações, como alimento e como espécie medicinal, as folhas desta espécie, quando secas, têm 10 vezes mais vitamina A que a cenoura, 15 vezes mais potássio que a banana, 17 vezes mais cálcio que o leite, 25 vezes mais ferro que o espinafre, 9 vezes mais proteína que o leite, e metade da vitamina $\mathrm{C}$ da laranja ${ }^{8}$. Existem inúmeras espécies indígenas ou de adaptação local com elevado valor nutricional e que são negligenciadas. Não raras vezes, o potencial existe e o alimento está acessível, necessitando contudo de intervenções no sentido de dar conhecer o seu valor e formas de ser usado.

A organização e o desenvolvimento de cadeias de valor para espécies locais, sub-exploradas, de elevado valor nutritivo, assumem-se como uma estratégia para melhoria da saúde, condições de vida e criação de renda para comunidades rurais, alavancando o desenvolvimento ao nível nacional.

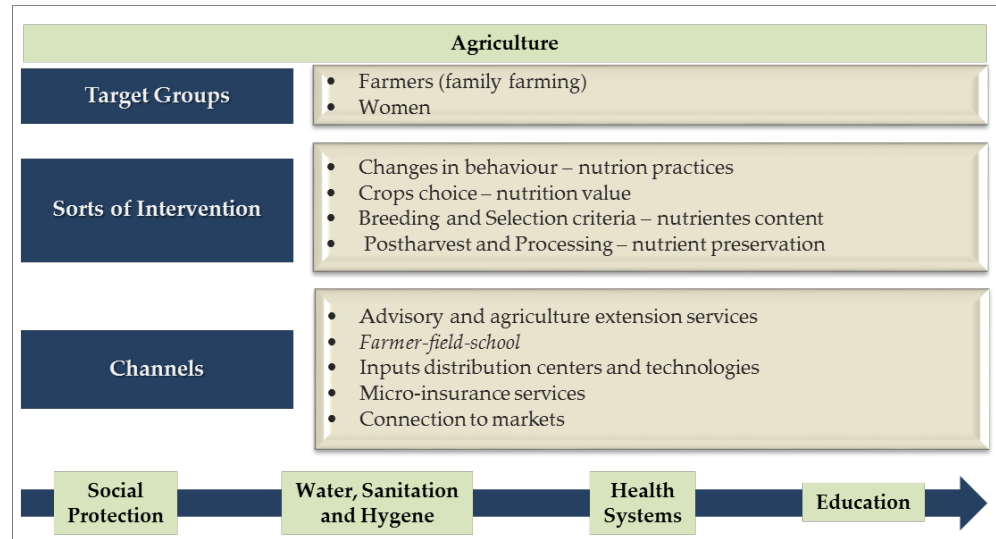

Figure 3 - Example of possible interventions to make agriculture more sensitive to nutrition. Note the mandatory requisite for complementary social protection policies, sanitation and hygiene, health and education (adapted from IFPRI ${ }^{7}$ ).

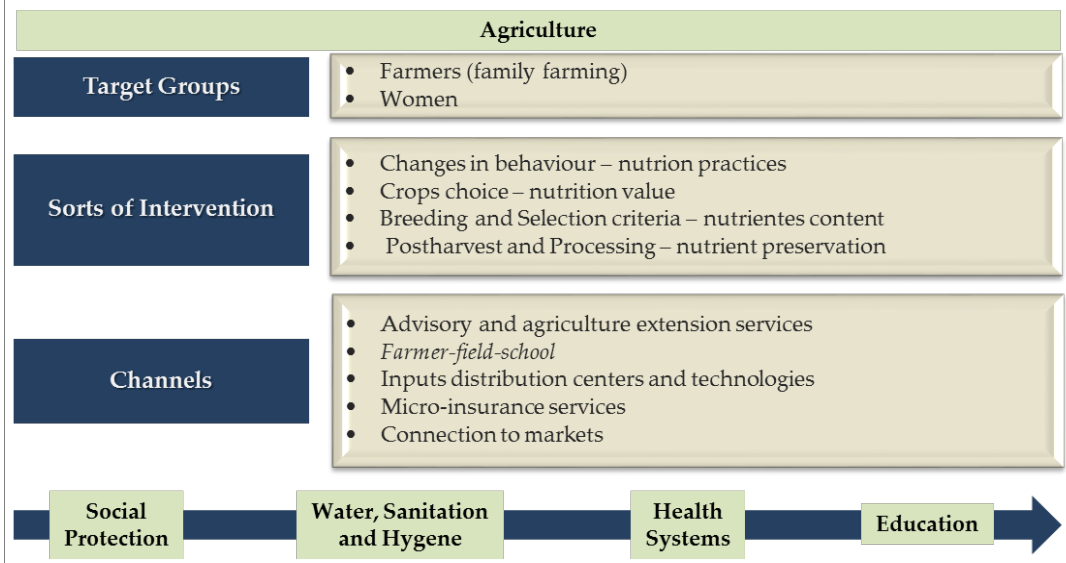

Figura 3 - Exemplo de intervenções a considerar para tornar a agricultura mais sensível à nutrição. Note-se o necessário acompanhamento por políticas de proteção social, saneamento e higiene, saúde e educação (adaptado de IFPRI ${ }^{7}$ ). 


\section{Challenges for the Portuguese-Speaking Countries Community}

Family farming ensures the majority of food production worldwide. Family smallholders rely on traditional species and crop diversification, locally-adapted indigenous knowledge and integration of sustainable use of natural resources and agrobiodiversity preservation. These characteristics are among the guidelines for agricultural sustainable intensification, under the "climate smart" scenario and cope with the incorporation of the nutrition dimension, in the food security definition. The "International Year of Family Farming," was an opportunity for awareness about the opportunity that these systems represent to boost economies and population prosperity, if accompanied by an appropriate policy framework and social protection.

To ensure that family farming can respond to the constant challenges and changes, it is therefore necessary to understand these systems' potential, needs and limitations, through a transdisciplinary approach that, in addition to the role of agricultural and agro-industrial technology and innovation, also includes health, social justice, environment, cultural diversity, entrepreneurship, economics or political dimensions.

Renovating the title of this text from "Interventions in agriculture to benefit nutrition and health in Portuguese-Speaking Countries" to "How to intervene in agriculture to benefit nutrition and health in Portuguese-Speaking Countries?" creates a challenge to the enormous Portuguese-speaking community to work together in "sharing and spread knowledge" through its common language, mutual knowledge and consolidated trust-rooted relationships.

Global challenges demand for regional and local reactions. Development is rooted in critical knowledge, innovation and training, which can then be translated into attitudes, competitive technical and leadership skills in agricultural advisory services, which are the main suppliers of the most significant FNS services. By sharing the same language, the "Portuguese-Speaking Countries Community region" has communication advantages, allowing dissemination of information and knowledge related to agricultural practices and to nutrition and health throughout all sectors of the society, including training, technical capacity building, awareness-raising campaigns and education, with the potential to lead to changes in behavior.

Framed by international cooperation, several Portuguese institutions have been participating in food safety and nutritional value research projects and education/ training activities, in collaboration with African Portu-

\section{Desafios para a CPLP}

A agricultura familiar assegura a produção da grande maioria dos alimentos ao nível mundial, apoiando-se no cultivo de espécies tradicionais e na diversificação da produção, utilizando conhecimentos indígenos e adaptados localmente e integrando o uso sustentável dos recursos naturais e proteção da agrobiodiversidade. Estas características inserem-se nas atuais diretrizes de intensificação agrícola, num contexto de sustentabilidade e agricultura "climate smart" e da integração da dimensão "nutrição", na definição de Segurança Alimentar. O "Ano Internacional da Agricultura Familiar" alertou para a oportunidade que estes sistemas representam para, com o adequado enquadramento de políticas e de proteção social, impulsionar as economias e o bem-estar das populações.

Para que a Agricultura Familiar possa responder aos constantes desafios e mudanças, é, pois, necessário compreender o potencial, as necessidades e as limitações destes sistemas, numa abordagem transdisciplinar que, além do papel da tecnologia e inovação agrícola e agroindustrial, inclui também componentes de saúde, justiça social, ambiente, diversidade cultural, empreendedorismo, economia ou política.

Transformar o título desta comunicação de "Intervir na agricultura em benefício da nutrição e da saúde na CPLP" em "Como intervir na agricultura em benefício da nutrição e da saúde na CPLP?" passa por desafiar a enorme comunidade de falantes da língua Portuguesa a trabalhar em conjunto, para "partilhar e transmitir saber" através de uma língua e conhecimento mútuo e de relações de confiança estabelecidas.

Desafios globais exigem respostas regionais e locais. O desenvolvimento alicerça-se no conhecimento crítico, e em inovação e capacitação que se traduzam em atitudes, em competências técnicas e de liderança, competitivas, nos serviços de aconselhamento agrário públicos, que são os principais fornecedores de serviços relevantes para a SAN. Ao partilhar a mesma língua, a "região CPLP" tem vantagens de comunicação, permitindo levar informação sobre práticas agrícolas e sobre nutrição e saúde a todos os setores da sociedade, incluindo formação e capacitação técnica e campanhas de sensibilização e educação, que levam a mudanças nos comportamentos.

Várias instituições Portuguesas, em iniciativas de cooperação, têm participado em projetos de investigação e em ações de capacitação, na temática da segurança e valor nutricional, em colaboração com países Africanos de Língua Portuguesa. Em todas as iniciativas, é necessário assegurar que as prioridades e as agendas 
guese-speaking countries. These initiatives have been attentive in ensuring that both priorities and schedules are locally established. Collaborations should endeavor consolidation of multi-sectorial knowledge networks, with a view of creating an active critical mass that is committed to "Science for Development", with scientific and technological innovative attitudes. Effective partnerships between research institutes, NGOs, private sector and universities emerge as renewed opportunities for North-South and North-South-South cooperation, towards a global target of improving the development and the living conditions of about 260 million people, of whom more than 25 million people do not have adequate access to food. Even though the situation is not identical in all countries, more than $80 \%$ of the CPLP food results from the activity of small farmers, together with virtually non-existent commercial and industrial processing circuits and deficient postharvest storage capacity.

Increased agricultural yield and productivity associated with adequate nutritional quality can be achieved through advanced capacity building and training to researchers, smallholders, technicians, teachers, and private sector and civil society leaders, working in all agricultural activity sectors and agribusiness support services. The current advisory services show gaps concerning advisors training in areas complementary to production and the skills need to be further developed and adapted to cover the entire value chain.

Universities, in conjunction with research institutions, stand as privileged actors to accomplish this goal, and have the potential to play a fundamental role in promoting family farming systems and ensure leveraging knowledge and expertise through research and through advisory services training, to ensure a continuous and sustainable supply of food, as:

- Knowledge and innovation creation requires additional study, training and skills development to be utilized;

- A transdisciplinary approach is mandatory to guarantee the significance, applicability and acceptance of knowledge and innovation;

- Increased agricultural yield and quality requires a persistent and planned training of extension technicians and agricultural extension services, which are responsible for the farmers' advice regarding that best practices that can be locally adapted;

- Continuous learning is required, to allow professionals, organizations and countries to acquire new knowledge and access to novel tools necessary to an adaptation to the needs and socio-economic context that is under rapid changes;

- The University delivers critical and independent sejam estabelecidas localmente e que as colaborações assentem na consolidação de redes multissetoriais de conhecimento, com vista à criação de uma massa crítica ativa e comprometida com a Ciência para o Desenvolvimento, com atitudes científicas e tecnológicas inovadoras. Parcerias efetivas entre institutos de investigação, ONGDs, privados e universidades representam renovadas oportunidades de colaboração Norte-Sul e Norte-Sul-Sul, para o grande objetivo de melhorar as condições de vida e o desenvolvimento de uma comunidade de cerca de 260 milhões de cidadãos, dos quais mais de 25 milhões de pessoas não têm acesso a uma alimentação adequada. Embora com realidades diferentes, mais de $80 \%$ dos bens alimentares na CPLP provêm de pequenos produtores agrícolas familiares, sendo que os circuitos comerciais e a transformação industrial são praticamente inexistentes e a capacidade de armazenamento é deficitária.

$\mathrm{O}$ aumento da produtividade agrícola associado a uma qualidade nutricional adequada, consegue-se através da capacitação humana avançada ao nível de investigadores, agricultores, técnicos, professores, líderes de setor privado e sociedade civil, em todos os serviços de suporte à atividade agrícola e agroindústria. Os serviços de aconselhamento atuais apresentam lacunas na formação quanto ao aconselhamento nas áreas complementares à produção e necessitam ser adaptados para cobrir toda a cadeia de valor.

As universidades, em articulação com instituições de investigação, são os atores privilegiados para o fazer, podendo desempenhar um papel fundamental na promoção de sistemas de Agricultura Familiar e assegurar a criação de conhecimento e competências através da investigação e de capacitação de serviços de aconselhamento, para garantir o fornecimento contínuo e sustentável de alimentos atendendo a que:

- A criação de conhecimento e inovação necessita de posterior ensino, capacitação e desenvolvimento de competências para que este possa ser utilizado;

- É necessária uma abordagem transdisciplinar para garantir a relevância, aplicabilidade e aceitação do conhecimento e inovação;

- O aumento da produtividade e qualidade agrícola exige uma constante e sólida capacitação de extensionistas agrícolas e dos serviços de extensão, que são responsáveis pelo aconselhamento dos agricultores quanto às melhores práticas adaptadas localmente;

- É necessária uma aprendizagem contínua, de modo a permitir aos profissionais, organizações e países a aquisição de novos conhecimentos e de ferramentas para adaptação às constantes e rápidas alterações das necessidades e contexto socioeconómico;

- A universidade produz pensamento crítico e indepen- 
thinking, "problem-solvers" and "team-players", which identify competencies gaps in all stakeholder groups and have the proper visibility and credibility among policy makers, legislators and consumer advocacy groups;

- The University's prominence, reputation and resident networks allow a coordination of FNS strategies, rules and regulations, which are still scattered throughout different institutions;

- The academic institutional networks and knowledge sharing platforms link society to the knowledge repositories to trigger innovation;

- The University has a leading role in understanding the context that is required for local adaptation of global innovations.

The challenges and needs required to adapt a knowledge transmission attitude towards change include:

- Curricula adaptation to make them more reactive and adapted to industry needs and societal challenges, with the involvement of the private sector;

- Continuous training and capacity building programs designed for experienced professionals. Sharing of experiences also benefits the Academia, by bringing practical aspects of knowledge, creativity and innovation to the educational process;

- New educational programs (short courses, training in work context, advanced tailor-made highly specialized training, distance learning), allowing expanding the target audience and tolerating for improving or recycling competences while working, without interrupting the professional activity;

- Inclusion of the "value chain" concept in academic curricula, promoting the linkage of small producers to the markets;

- Strengthening partnerships with extension technicians and advisory services for knowledge translation and reduction of the distance between the experimental research results and field agricultural practices, and promoting a dialogue between them;

- Involvement of youth, with emphasis on women, in the agricultural sector, through promotion of a modern image of the sector (e.g., role of mechanization and information and communication technologies) that allows good life quality standards, safeguarding the continuity of family farming, with an additional impact in job creation;

- Establishment of functional and inclusive innovation platforms and information sharing mechanisms;

- Design of innovative mechanisms for disseminating research results and innovation to smallholders, to farmers and to the industry; dente, "problem-solvers" e "team-players", que identificam lacunas nas competências em todos os grupos intervenientes e tem voz junto de governantes e de grupos de defesa de consumidores;

- A visibilidade, prestigio e redes existentes na universidade permitem coordenar as regulamentações quanto à SAN que estão dispersas por diferentes instituições;

- As redes e plataformas institucionais de partilha de informação, com base na Academia, fazem a ligação entre a sociedade e os repositórios de conhecimento, estimulando a inovação;

- A universidade tem um papel de destaque na compreensão do contexto para adaptação local de inovação global ou produzida em diferentes enquadramentos.

Os desafios e necessidades que se colocam para adaptar a atitude da transmissão de conhecimento face à mudança incluem:

- Adaptação de curricula para os tornar mais reativos e adaptados às necessidades do mercado de trabalho e desafios societais, com o envolvimento do setor privado;

- Programas de capacitação contínua, para profissionais com experiência. A partilha de experiências de terreno beneficia também a academia, trazendo conhecimento prático, criatividade e inovação ao processo de ensino; - Novos programas de educação (cursos de curta duração, formação em contexto de trabalho, formação em temas altamente especializados, ensino à distância), permitindo alargar o leque de destinatários e permitir obter formação sem suspender a atividade profissional; - Inclusão do conceito de "cadeia de valor" nos curricula, promovendo a ligação dos pequenos produtores aos mercados;

- Fortalecimento de parcerias com extensionistas e agências de aconselhamento para tradução do conhecimento e reduzir a distância entre os resultados de investigação laboratorial/campo e as práticas agrícolas no terreno, promovendo diálogo entre os intervenientes na prestação de serviços de extensão e aconselhamento agrícola;

- Envolvimento de jovens, com ênfase nas mulheres, no setor agrícola, através da promoção de uma imagem moderna do setor (ex: mecanização e tecnologias de informação e comunicação) que permite ter um nível de vida digno, assegurando a continuidade dos sistemas de agricultura familiar, com consequência também na criação de emprego;

- Criação de plataformas funcionais e inclusivas de promoção de inovação e mecanismos de partilha de informação;

- Desenho de mecanismos inovadores de disseminação de resultados de investigação e de inovação para agricultores e indústria; 
- Inclusion of entrepreneurship concepts in the agricultural academic curricula (including communication, negotiation and management skills);

- Leverage agribusiness by hosting business incubators and facilitating entrepreneurs with access to credit.

These priorities echo the main recent CONSAN-CPLP resolutions, as stated. During the I Extraordinary Meeting, the ratification of the guidelines concerning the constitution and functioning of a CONSAN-CPLP Participation Facilitation Mechanism was agreed: i) Higher education organizations, by encouraging the integration of research institutions and other relevant stakeholders; II) Private sector, which should ensure a commitment to the agriculture and food system responsible investment principles; III) Legislators, articulated and with the support of FAO. Regarding nutrition in agriculture, it was further recommended that the activities held in health and nutrition contexts through the CONSAN-CPLP Participation Facilitation Mechanism and through a CONSAN-CPLP Family Farming Working Group (GTAF), together with those under the World Food Security Committee framework, will contribute to: leveraging the establishment of a Health and $\mathrm{Nu}-$ trition Working Group; creating a competence center and technology transfer network to support capacity building for sustainable family farming in the CPLP; developing primary, secondary and higher education programs that address agroecology, nutrition, gender equality roles in accessing healthy and nutritive foods through a coordination between the ministries of agriculture, education and health; developing thematic training programs targeting the human right to adequate food, identified by different stakeholders as graduate level and short courses priorities, through conventional attendance and/or distance learning; identifying and prioritizing a research agenda for production and access to food in the context of the commitments undertaken in the Human Right to Adequate Food Progressive Realization voluntary guidelines, under the context of $\mathrm{Na}$ tional Food Security and ESAN-CPLP, in partnership with civil society, universities, research institutions and other relevant actors.

\section{Conflict of interests}

The authors declare that there are no financial and/or personal relationships that could be viewed as presenting a potential conflict of interests.
- Inclusão do conceito de empreendedorismo nos curricula agrícolas (incluindo comunicação, negociação e gestão);

- Alavancar a criação de agronegócio através do acolhimento de incubadoras de empresas e acesso a crédito para empreendedores.

Estas prioridades alinham-se com as principais deliberações tomadas recentemente pelo CONSAN-CPLP. Durante a sua I Reunião Extraordinária, ficou decidido ratificar as diretrizes relativas à constituição e funcionamento do Mecanismo de Facilitação da Participação no CONSAN-CPLP de: i) Organizações do Ensino Superior, estimulando a integração das instituições de investigação e pesquisa e outros atores relevantes neste mecanismo; ii) Setor Privado, que deverá assegurar um compromisso com os Princípios para o Investimento Responsável na Agricultura e no Sistema Alimentar; iii) Parlamentares, em articulação e com o apoio da FAO. No que diz respeito ao aspeto da nutrição na agricultura, foi ainda recomendado que as atividades já desenvolvidas no âmbito da Nutrição e Saúde pelos Mecanismos de Participação no CONSAN-CPLP e GTAF CONSAN-CPLP, bem como no âmbito do Comité Mundial de Segurança Alimentar, contribuam para a dinamização de um Grupo de Trabalho em Saúde e Nutrição; a criação de um Centro de competências e rede de transferência de tecnologias que apoie a construção de capacidades para a agricultura familiar sustentável na CPLP; o desenvolvimento de programas de inclusão da agroecologia, nutrição e redução das desigualdades de género e geração no acesso a uma alimentação saudável, nos ensinos primário, secundário e superior, mediante coordenação entre os Ministérios da Agricultura, da Educação e da Saúde; o desenvolvimento de programas de formação em temáticas para o Direito Humano à Alimentação Adequada, identificadas pelos diferentes atores como prioritárias, quer ao nível da pós-graduação, quer em cursos de curta duração, através de ensino presencial e/ou à distância; a identificação e prioritização de uma agenda de investigação para produção e acesso à alimentação saudável no contexto dos compromissos assumidos nas Diretrizes Voluntárias para a Realização Progressiva do Direito Humano à Alimentação Adequada no contexto da Segurança Alimentar Nacional e na ESAN - CPLP, em parceria com a sociedade civil, universidades, instituições de investigação e pesquisa e outros atores relevantes.

\section{Conflito de interesses}

O autor declara que não há conflito de interesses de qualquer natureza. 


\section{References/ Referências}

1. International Food Policy Research Institute. Global Hunger Index: The Challenge of Hidden Hunger. 2014 Bonn/Washington, D.C./ Dublin.

2. Biesalski HK. Hidden Hunger. Springer Spektrum. 2013.

3. Black R E, Victora C, Walker SP, Bhutta ZA, Christian P, De Onis M, Ezzati M, Grantham-McGregor S, Katz J, Martorell R, Uauy R. Maternal and Child Undernutrition and Overweight in Low- and Middle-Income Countries. 2013; The Lancet 382: 427-451.

4. Le Cuziat G, Mattinen H. Maximising the Nutritional Impact of Food Security and Livelihood Interventions: A Manual for Field Workers. 2011. ACF International. New York.

5. World Bank. World Development Report: Agriculture for Development. 2008.
6. Gelli A, Hawkes C, Donovan J, Harris J, Allen S, de Brauw A, Henson S, Johnson N, Garrett J, Ryckembusch D. Value Chains and Nutrition: A Framework to Support the Identification, Design, and Evaluation of Interventions. 2015; IFPRI Discussion Paper 01413.

7. International Food Policy Research Institute. Global Nutrition Report 2014: Actions and Accountability to Accelerate the World's Progress on Nutrition. 2014. Washington, DC.

8. Gopalan C, Rama Sastri BV, Balasubramanian SC. Nutritive Value of Indian Foods Hyderabad, India. 1971. 